Original Research

\title{
Surface Activation of Elderberry, Gooseberry and Paprika Residues with Acetic Acid to Improve Quality of Biosorption Processes of $\mathrm{Cu}(\mathrm{II})$, $\mathrm{Cd}(\mathrm{II})$ and $\mathrm{Fe}(\mathrm{III})$
}

\author{
Tomasz Kalak ${ }^{1 *}$, Joanna Dudczak-Hałabuda ${ }^{1}$, Yu Tachibana ${ }^{2}$, \\ Ryszard Cierpiszewski ${ }^{1}$ \\ ${ }^{11}$ Poznań University of Economics and Business, Institute of Quality Science, Department of Industrial \\ Products and Packaging Quality, Poland \\ ${ }^{2}$ Department of Nuclear System Safety Engineering, Graduate School of Engineering, Nagaoka University \\ of Technology, 1603-1, Japan
}

Received: 9 March 2020

Accepted: 17 July 2020

\begin{abstract}
The residues of elderberry (Sambucus nigra L.), gooseberry (Ribes uva-crispa L.) and paprika (Capsicum annuum L.) generated during food processing were modified with acetic acid to show the effect on the bioremoval process efficiency of $\mathrm{Cu}(\mathrm{II}), \mathrm{Cd}(\mathrm{II})$ and $\mathrm{Fe}(\mathrm{III})$ ions from aqueous solutions. The biomaterials were characterized using several methods, including particle size distribution, SEMEDS, BET, BJH, morphology (SEM), FT-IR. Based on the kinetics analysis the pseudo second-order kinetic model fit better in relation to the research results. The bioremoval processes followed well the Langmuir isotherms model with high correlation coefficients. This study showed that the chemical modification of the tested materials had a positive impact on improving the efficiency of the biosorption processes. Modified biowaste can be used as effective and environmentally friendly sorbents to remove heavy metal ions from wastewater to improve water quality.
\end{abstract}

Keywords: water quality, heavy metal ions, chemical modification, biosorption quality, biomass residues

\section{Introduction}

Global water pollution is a worrying phenomenon and is becoming the subject of increasing interest among many scientific centers, organizations and

*e-mail: tomasz.kalak@ue.poznan.pl governments around the world. Supplying clean water to meet human needs in industrialized countries and those with significant water shortages is a priority in today's dynamic development of various technologies and industries $[1,2]$. Organic and inorganic pollutants are produced in various industries, and their concentration in fresh water above the permissible limits has a negative impact on water quality and makes it unfit for consumption. The increased industrial use of 
chemicals and metals is reflected in the production of increased amounts of wastewater containing high levels of toxic heavy metals, including $\mathrm{Cu}, \mathrm{Cr}, \mathrm{Cd}, \mathrm{Hg}, \mathrm{Ni}, \mathrm{Pb}$, As, Fe, etc. [3, 4]. They are produced during processes in mining, metallurgy, electroplating, tanneries, pulp, automotive, aviation industries and many others. If these pollutant streams enter the environment continuously without effective purification, this can lead to serious environmental degradation. Due to bioaccumulation, non-biodegradability and persistence in ecosystems, heavy metals have a direct toxic effect on living organisms, human health, causing metabolic and chronic disorders, diseases of many organs, systems and cancer. In order to reduce harmful pollution, there is an urgent need for water treatment for the purification of industrial wastewater from heavy metals to acceptable limits before discharging into water [5].

Several conventional methods are used to remove heavy metals from wastewater, such as membrane processes, ion exchange, precipitation, flotation, coagulation, etc. [6]. Many of them have disadvantages in the form of technical restrictions or very high costs. Among alternative methods, the biosorption process, which is cheaper technique due to the uncomplicated operation procedure and the possibility of using biomass waste from industrial processing, deserves special attention. Examples of biowastes that can be used in adsorption processes are elderberry, gooseberry and paprika pomace generated in the food industry. They are rich in many organic fiber components containing appropriate functional groups responsible for the ability to bind metal ions by chemical and physical means $[7,8]$. In our laboratory, these biosorbents have been examined for the possibility of removing selected metal ions from aqueous solutions. The results were not satisfactory in the case of copper and cadmium, thus it was decided to apply chemical modification to increase their adsorptive capacity.

The main purpose of these studies was to investigate the impact of surface modification of elderberry (Sambucus nigra L.), gooseberry (Ribes uva-crispa L.) and paprika (Capsicum annuum L.) pomace with acetic acid on biosorption efficiency of $\mathrm{Cu}$ (II), $\mathrm{Cd}$ (II) and $\mathrm{Fe}$ (III) ions from aqueous solutions. The biowaste was generated from processing in the food industry in Poland and characterized in terms of physical and chemical properties. The experiments were conducted under different conditions of biosorbent dosage, initial concentration and contact time. Furthermore, the sorption kinetics, equilibrium and the Langmuir and Freundlich isotherms were studied.

\section{Material and Methods}

\section{Preparation of Biosorbents}

Elderberry (Sambucus nigra L.), gooseberry (Ribes uva-crispa L.) and paprika (Capsicum annuum
L.) residues were obtained during processing of the food industry in Poland. The samples were crumbled, sieved and separated into individual fractions with the following particle diameter ranges: $0-0.212 \mathrm{~mm}$, $0.212-0.500 \mathrm{~mm}, 0.500-1.0 \mathrm{~mm}, 1.0-1.7 \mathrm{~mm},>1.7$ $\mathrm{mm}$. Next, they were dried at $60^{\circ} \mathrm{C}$ (dryer BINDER Gmbh, Tuttlingen, Germany) and afterwards kept in a desiccator before experiments.

\section{Biomass Characterization}

The elderberry, gooseberry and paprika particles between 0 and $0.212 \mathrm{~mm}$ in diameter were used in the research studies. Firstly, the properties of the biomass were examined using several methods, including: 1) particle size distribution by the laser diffraction method using a Zetasizer Nano ZS (Malvern Instruments Ltd., UK); 2) the elemental composition using a scanning electron microscope (SEM) Hitachi S-3700N with an attached a Noran SIX energy dispersive X-ray spectrometer (EDS) microanalyser (ultra-dry silicon drift type with resolution (FWHM) $129 \mathrm{eV}$, accelerating voltage: $20.0 \mathrm{kV}$ ); 3) the specific surface area and the average pore diameter by the BET method using Autosorb iQ Station 2 (Quantachrome Instruments, USA); 4) the pore volume by the $\mathrm{BJH}$ method using Autosorb iQ Station 2 (Quantachrome Instruments, USA); 5) the morphology by a scanning electron microscope (SEM) EVO-40 (Carl Zeiss, Germany); 6) the surface structure analysis by a Fourier transform attenuated total reflection (FT-IR ATR) Spectrum 100 (Perkin-Elmer, Waltham, USA).

\section{Metal Ions Adsorption Process}

The biosorbents were modified with acetic acid by shaking in acid solution (5\% and 10\%) for $60 \mathrm{~min}$ at $150 \mathrm{rpm}$. The removal efficiency of $\mathrm{Cu}(\mathrm{II}), \mathrm{Cd}(\mathrm{II})$ and $\mathrm{Fe}(\mathrm{III})$ ions (with analytical purity, standards for AAS $1 \mathrm{~g} / \mathrm{L}$, Sigma-Aldrich) were determined in batch experiments at room temperature $\left(23 \pm 1^{\circ} \mathrm{C}\right)$. The dried particles of the biomass residues $(2.5-100 \mathrm{~g} / \mathrm{L})$ and a portion of metal ions solution $(9-12 \mathrm{mg} / \mathrm{L})$ at $\mathrm{pH} 4$ were shaken during $60 \mathrm{~min}$ at $150 \mathrm{rpm}$. The $\mathrm{pH}$ metal solutions were adjusted using $0.1 \mathrm{M} \mathrm{NaOH}$ and $\mathrm{HCl}$. Subsequently, the solutions were centrifuged at 4000 $\mathrm{rpm}$ to separate the phases. Finally, the metal ions concentration $[\mathrm{mg} / \mathrm{L}]$ was determined by the atomic absorption spectrophotometer (F-AAS, at a wavelength $\lambda=324.8 \mathrm{~nm}$ for copper, $\lambda=228.8 \mathrm{~nm}$ for cadmium, $\lambda=248.3 \mathrm{~nm}$ for iron) SpectrAA 800 (Varian, Palo Alto, USA). Distilled water was used in all experiments, measurements were repeated three times and average results were presented.

The bioremoval efficiency $A[\%]$ and capacity $q_{e}$ $[\mathrm{mg} / \mathrm{g}]$ were calculated in accordance with the equations 1 and 2, respectively: 
Table 1. The average elemental composition of biosorbents.

\begin{tabular}{|c|c|c|c|c|c|c|c|c|c|c|c|c|c|}
\hline Elements & $\mathrm{C}$ & $\mathrm{O}$ & $\mathrm{Na}$ & $\mathrm{Mg}$ & $\mathrm{Al}$ & $\mathrm{Si}$ & $\mathrm{P}$ & $\mathrm{K}$ & $\mathrm{Ca}$ & $\mathrm{Ti}$ & $\mathrm{Fe}$ & $\mathrm{S}$ \\
\hline Biomass & \multicolumn{10}{|c|}{ Weight [\%] } \\
\hline Elderberry & 41.26 & 26.45 & 1.55 & 2.33 & 5.29 & 7.39 & 5.45 & 4.28 & 1.71 & & 0.78 & 3.5 \\
\hline Gooseberry & 19.3 & 53.59 & 0.85 & 0.78 & 7.58 & 13.85 & 0.29 & 1.36 & 0.5 & 0.14 & 1.76 & - \\
\hline Paprika & 44,51 & 41,03 & - & 2,07 & 2,3 & 1,84 & 3,27 & 0,92 & 0,83 & - & - & 3,23 \\
\hline
\end{tabular}

$$
\begin{gathered}
A=\left[\frac{C_{0}-C_{e}}{C_{0}}\right] \times 100 \% \\
q_{e}=\frac{\left(C_{0}-C_{e}\right) \times V}{\mathrm{~m}}
\end{gathered}
$$

...where: $C_{0}$ and $C_{e}[\mathrm{mg} / \mathrm{L}]$ are initial and equilibrium metal ion concentrations, respectively; $V[\mathrm{~L}]$ - volume of solution and $m[\mathrm{~g}]$ - mass of a biosorbent.

Kinetics and isotherm parameters were calculated using pseudo-first-order (3) and pseudo-second-order (4), Langmuir (5) and Freundlich (6) models according to the equations, respectively:

$$
\begin{gathered}
q_{t}=q_{e}\left(1-e^{k_{1} t}\right) \\
q_{t}=\frac{q_{e}^{2} k_{2} t}{1+q_{e} k_{2} t} \\
q_{e}=\frac{q_{\max K_{L} C_{e}}}{1+K_{L} C_{e}} \\
q_{e}=K_{F} C_{e}^{\frac{1}{n}}
\end{gathered}
$$

...where: $q_{t}[\mathrm{mg} / \mathrm{g}]$ is the amount of metal ions adsorbed at any time $t$ [min.]; $q_{e}[\mathrm{mg} / \mathrm{g}]$ - the maximum amount of metal ions adsorbed per mass of the biosorbent at equilibrium; $k_{1}[1 / \mathrm{min}$.] - the rate constant of pseudofirst-order adsorption; $k_{2}[\mathrm{~g} /(\mathrm{mg} \cdot \mathrm{min})$.$] - the rate$ constant of pseudo-second-order adsorption; $q_{\max }(\mathrm{mg} / \mathrm{g})$ - the maximum adsorption capacity; $K_{L}$ - the Langmuir constant; $C_{e}[\mathrm{mg} / \mathrm{L}]$ - the equilibrium concentration after the adsorption process; $K_{F}$ - the Freundlich constant and $1 / n$ - the intensity of adsorption.

\section{Results and Discussion}

\section{Characterization of the Elderberry, Gooseberry and Paprika Biomass}

The particle size distribution of elderberry, gooseberry and paprika residues by laser diffraction were examined. The following peaks were observed: $77.0 \mathrm{~nm}$ (elderberry), $68.6 \mathrm{~nm}$ (gooseberry) and 1.5, 32.7, 122.4 and $295.3 \mathrm{~nm}$ (paprika). It should be clarified that the limitation of this analysis was that not all biomass particles suspended in the solution (larger particles fell to the bottom of the solution). For this reason, only analysis of suspended particles was possible. The elemental analysis was conducted using the SEM-EDS method. The results are shown in Table 1. The presence of the largest number of carbon and oxygen atoms in the analyzed organic biomass was observed. The content of elements was calculated based on the number of counts in the EDS microanalysis. The material is not homogeneous, so there may be differences in the quantitative and qualitative composition depending on the location of the measuring point on the sample by the SEM-EDS method. Similar analysis results have been found in the literature for other fruit waste from the food industry [9].

The specific surface area $\left(\mathrm{S}_{\mathrm{BET}}\right)$, volume of the pores $(\mathrm{Vp})$ and average pore diameter (Apd) were determined using the BET analysis and achieved parameters are shown in Table 2. Based on the analysis of adsorption and desorption isotherms (Fig. 1a-c), it can be assumed that they better match the Type II adsorption behaviour. The flat surface of the curves in the middle is related to the formation of a monolayer. According to Ambroz et al. [10], the reversible type II isotherm corresponds to porous or non-porous materials. The initial fragment of the isotherm is associated with monolayer coating. When the monolayer coating is finished, the change in curvature is sharp. However, the onset of multilayer adsorption (monolayer overlap) is characteristic of a more gradual curvature [10]. All the biomass particles contain pores between 2 and $50 \mathrm{~nm}$ in diameter, therefore they belong to the mesopores group [11]. Furthermore, the analysis of pore volume distribution was performed by the BJH method (associated with capillary condensation in mesopores) and the parameters are presented in Table 3.

Table 2. Summary of BET adsorption and desorption parameters.

\begin{tabular}{|c|c|c|c|}
\hline Parameters & Elderberry & Gooseberry & Paprika \\
\hline $\begin{array}{c}\text { Specific surface area } \\
\left(\mathrm{S}_{\mathrm{BET}}\right)\left[\mathrm{m}^{2} / \mathrm{g}\right]\end{array}$ & 2.642 & 5.231 & 3.446 \\
\hline Pore volume $(\mathrm{Vp})\left[\mathrm{cm}^{3} / \mathrm{g}\right]$ & 0.0025 & 0.0045 & 0.0055 \\
\hline Pore diameter $(\mathrm{Apd})[\mathrm{nm}]$ & 3.85 & 3.44 & 6.415 \\
\hline
\end{tabular}




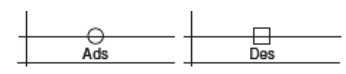

a)
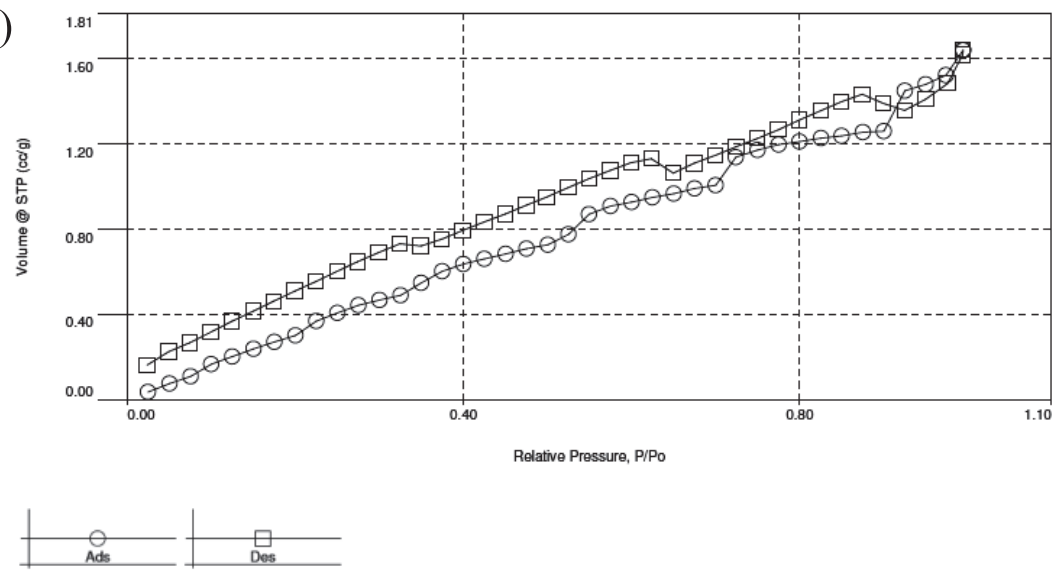

b)
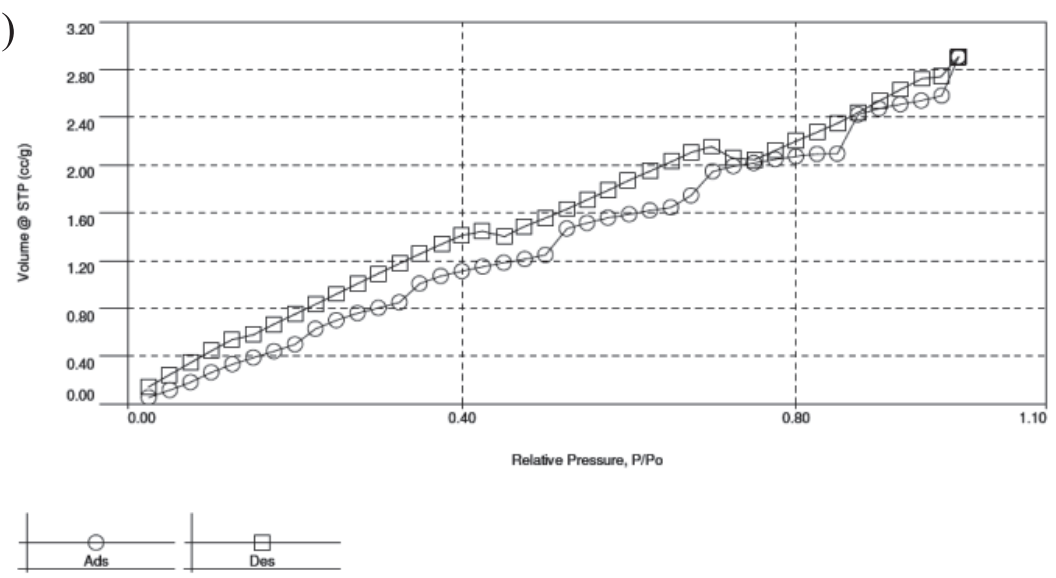

c)

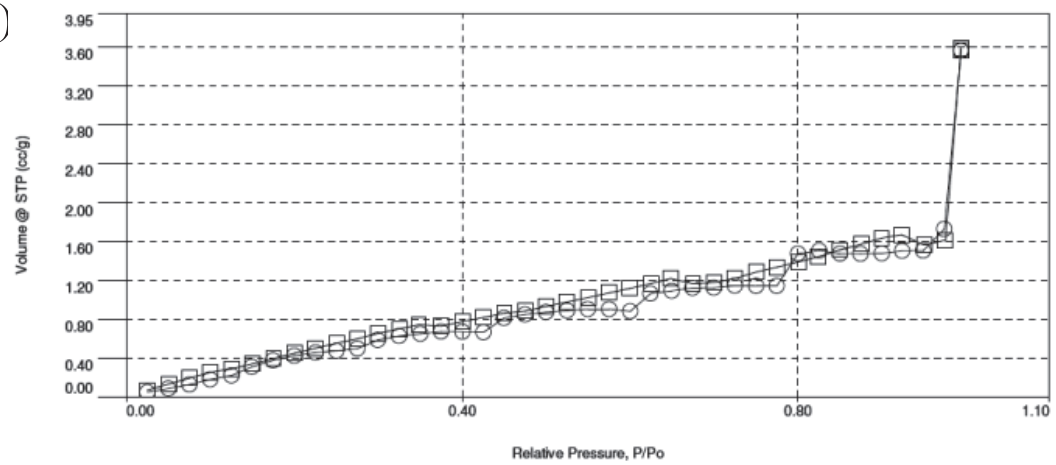

Fig. 1. The low temperature BET adsorption and desorption isotherms: a) elderberry, b) gooseberry, c) paprika residues.

\section{Adsorption Studies of $\mathrm{Cu}(\mathrm{II}), \mathrm{Cd}(\mathrm{II})$ and $\mathrm{Fe}(\mathrm{III})$ Biosorption}

\section{Impact of Biosorbent Dosage}

The impact of adsorbent dosage on the bioremoval efficiency of $\mathrm{Cu}(\mathrm{II}), \quad \mathrm{Cd}(\mathrm{II})$ and $\mathrm{Fe}(\mathrm{III})$ from aqueous solutions before and after modification with acetic acid was studied and the results are shown in Figs 2-4 (a-c). The experimental conditions were set based on our previous research achievements [12-14] and were as follows: the initial concentration range of metal ions $9-12 \mathrm{mg} / \mathrm{L}$, initial $\mathrm{pH} 4$, contact time $60 \mathrm{~min}$, temperature $\mathrm{T}=23 \pm 1^{\circ} \mathrm{C}$, rotational speed $150 \mathrm{rpm}$.
According to the results, the biosorption efficiency increased with an increase in the dosage up to $100 \mathrm{~g} / \mathrm{L}$. Surface modification with acetic acid $(5 \%$ and $10 \%$ ) resulted in growth of process efficiency in case of $\mathrm{Cu}(\mathrm{II})$ and $\mathrm{Cd}(\mathrm{II})$ removal. The highest values were obtained at $100 \mathrm{~g} / \mathrm{L}$, thus it can be considered as optimal. The greatest and average values of achieved adsorption efficiency after modification are summarized in Table 4. As it is seen, the best improvement is reported in case of the removal of $\mathrm{Cu}$ (II) by gooseberry pomace $\left(97.3 \%, 33.3 \%\right.$ on average, $\left.10 \% \mathrm{CH}_{3} \mathrm{COOH}\right)$. Lower improvement was observed during the reaction with $\mathrm{Cd}(\mathrm{II})$ ions (form $6.7 \%$ to 28.0 on average). In all cases of processes, the modification caused an increase 
Table 3. Summary of BJH adsorption and desorption parameters.

\begin{tabular}{|c|c|c|c|c|}
\hline Parameters & & Elderberry & Gooseberry & Paprika \\
\hline Specific surface area $\left(\mathrm{S}_{\mathrm{BET}}\right)\left[\mathrm{m}^{2} / \mathrm{g}\right]$ & \multirow{3}{*}{ Adsorption } & 1.478 & 2.125 & 1.673 \\
\hline Pore volume $(\mathrm{Vp})\left[\mathrm{cm}^{3} / \mathrm{g}\right]$ & & 0.002 & 0.004 & 0.006 \\
\hline Pore diameter (Apd) $[\mathrm{nm}]$ & & 2.973 & 4.184 & 3.511 \\
\hline Specific surface area $\left(\mathrm{S}_{\mathrm{BET}}\right)\left[\mathrm{m}^{2} / \mathrm{g}\right]$ & \multirow{3}{*}{ Desorption } & 1.397 & 2.331 & 1.599 \\
\hline Pore volume $(\mathrm{Vp})\left[\mathrm{cm}^{3} / \mathrm{g}\right]$ & & 0.002 & 0.004 & 0.005 \\
\hline Pore diameter (Apd) $[\mathrm{nm}]$ & & 3.137 & 3.140 & 3.142 \\
\hline
\end{tabular}

in adsorption capacity, which systematically decreased as the adsorbent mass increased (generally in the range from 3.9 to $0.1 \mathrm{mg} / \mathrm{g}$ ). Sha et al. also reported
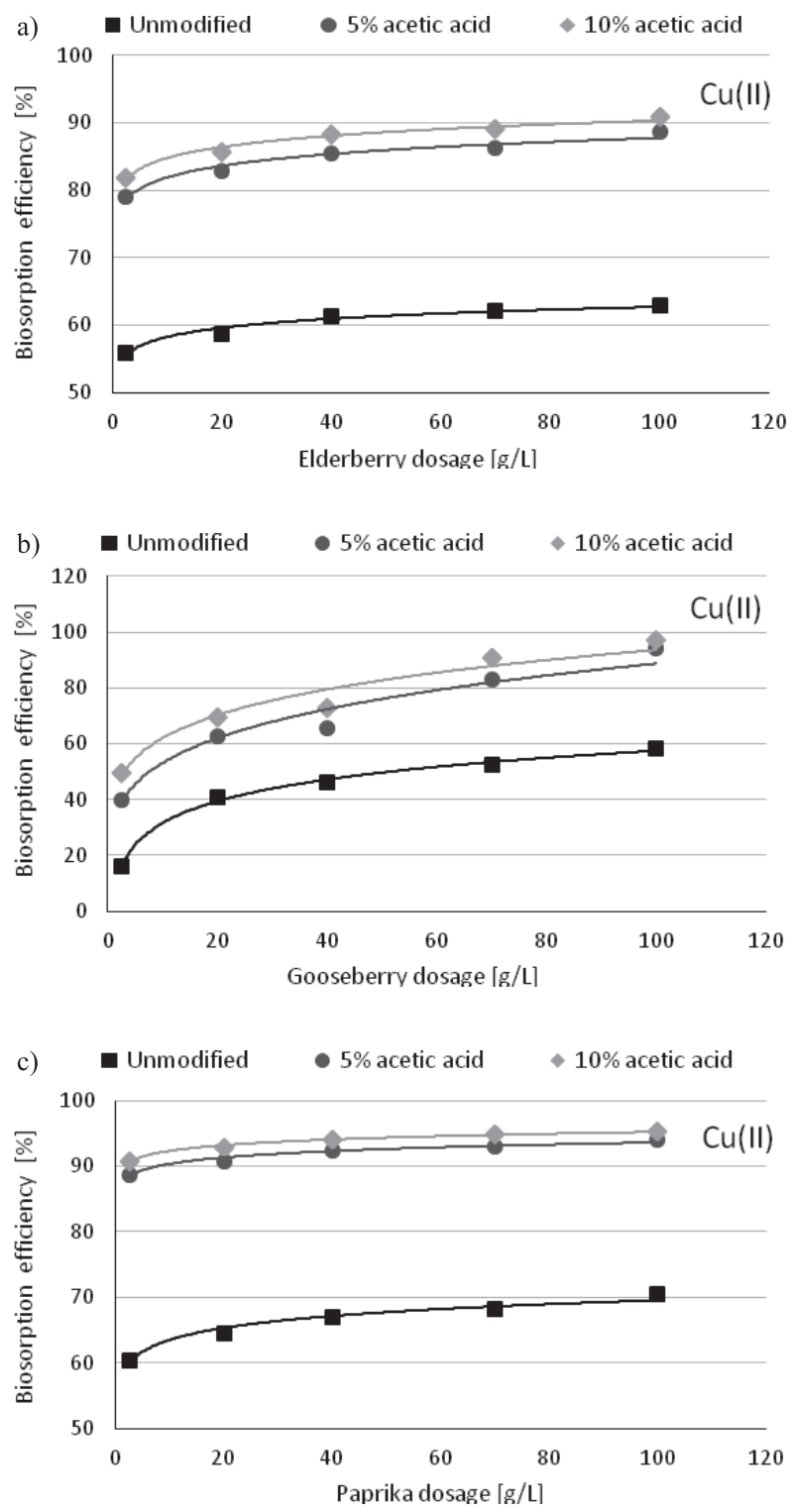

Fig. 2. Effect of adsorbent dosage on removal efficiency of $\mathrm{Cu}$ (II) by $\mathrm{CH}_{3} \mathrm{COOH}$-modified: a) elderberry, b) gooseberry, c) paprika residues (initial concentration of $\mathrm{Cu}$ (II) $10.87 \mathrm{mg} / \mathrm{L}$; initial $\mathrm{pH} 4)$. the positive effect of acetic acid modification on the biosorption of $\mathrm{Cu}(\mathrm{II})$ and $\mathrm{Cd}(\mathrm{II})$ ions with orange peel [15].
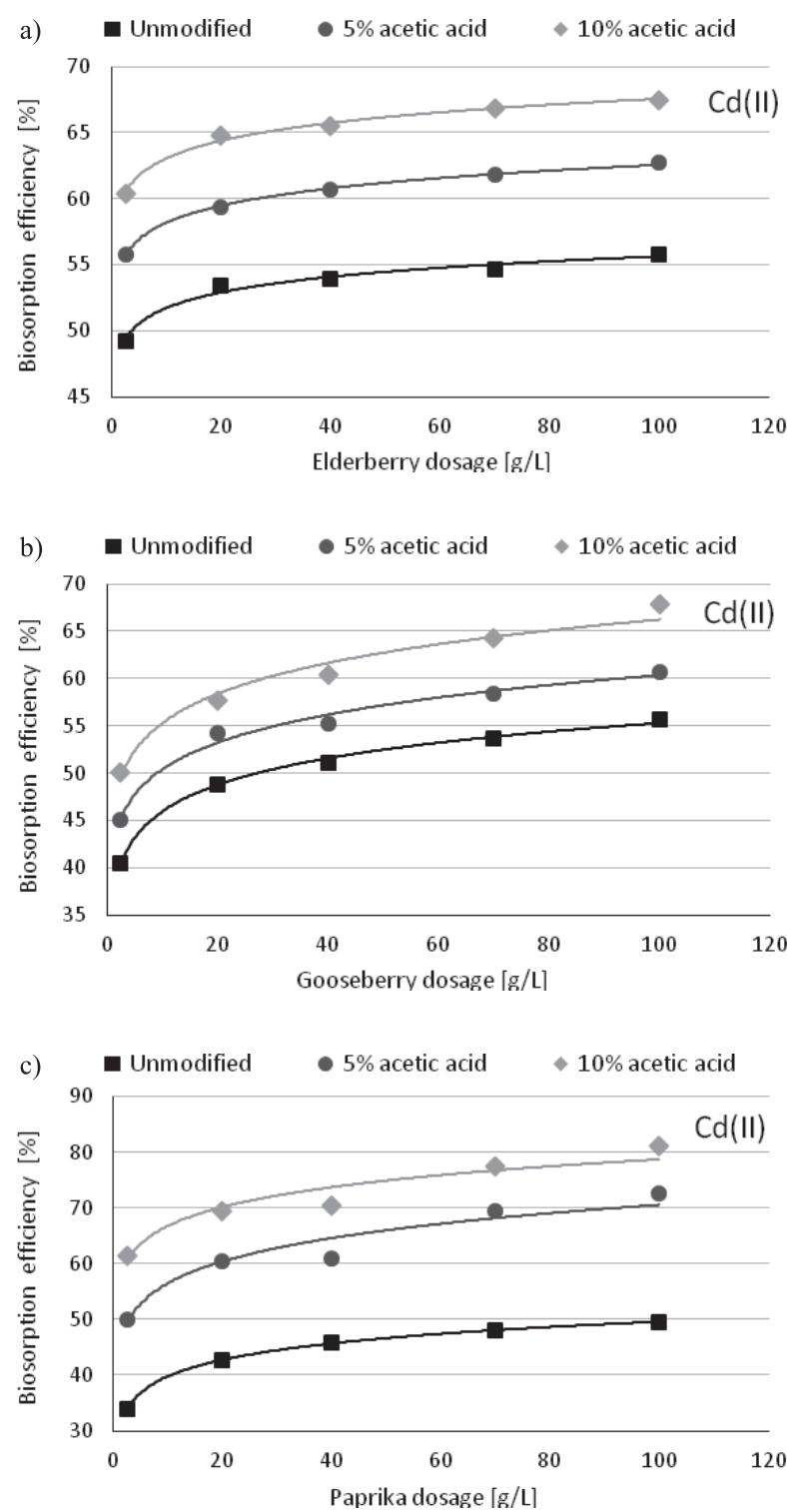

Fig. 3. Effect of adsorbent dosage on removal efficiency of $\mathrm{Cd}$ (II) by $\mathrm{CH}_{3} \mathrm{COOH}$-modified: a) elderberry, b) gooseberry, c) paprika residues (initial concentration of $\mathrm{Cd}(\mathrm{II}) 11.56 \mathrm{mg} / \mathrm{L}$; initial $\mathrm{pH} 4)$. 

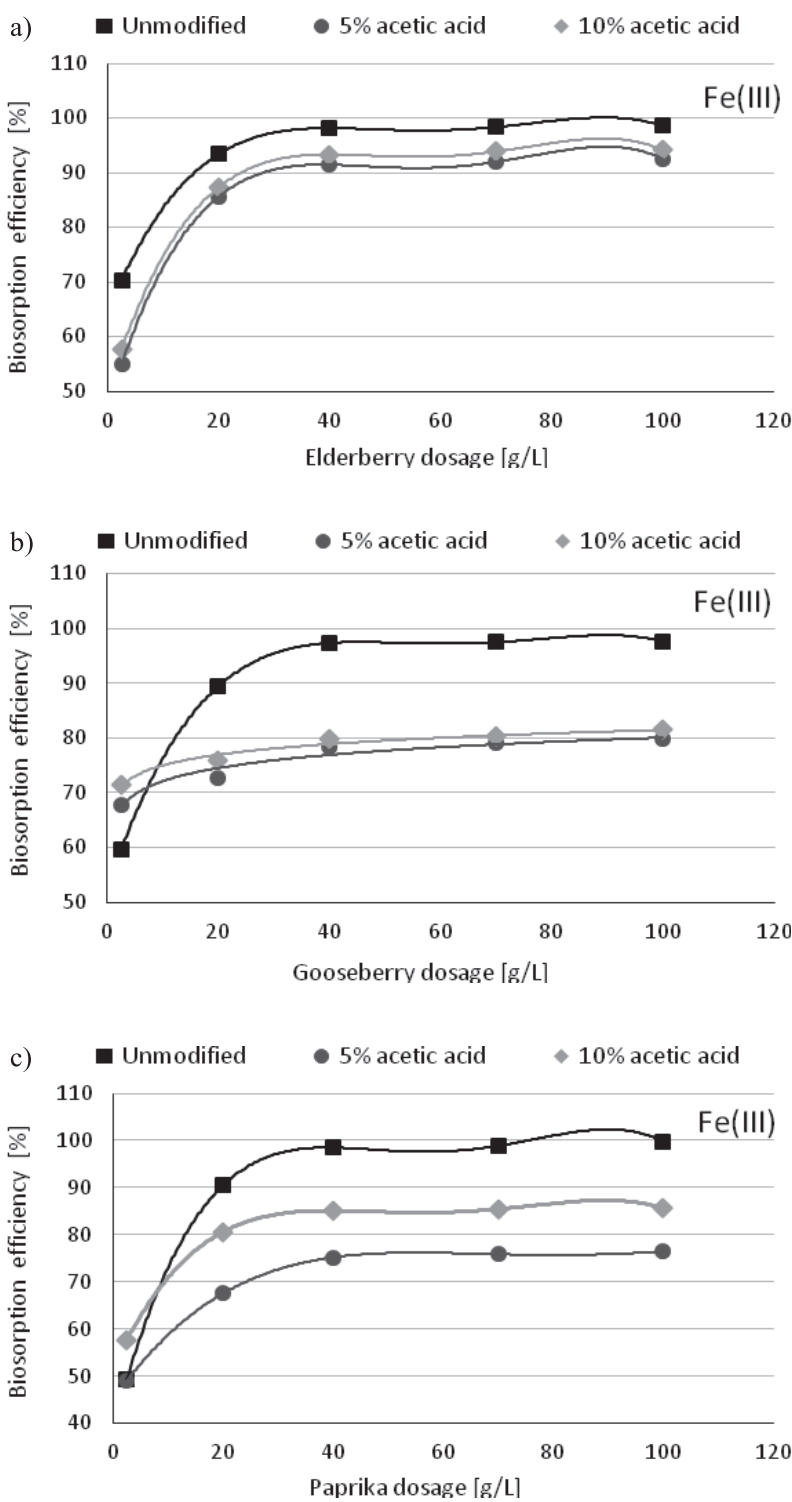

Fig. 4. Effect of adsorbent dosage on removal efficiency of $\mathrm{Fe}(\mathrm{III})$ by $\mathrm{CH}_{3} \mathrm{COOH}$-modified: a) elderberry, b) gooseberry, c) paprika residues (initial concentration of Fe(III) $9.24 \mathrm{mg} / \mathrm{L}$; initial $\mathrm{pH} 4)$.

The tested biosorbents showed very high ability to remove $\mathrm{Fe}(\mathrm{III})$ ions without modification. The experimental conditions were the same as in case of
$\mathrm{Cu}(\mathrm{II})$ and $\mathrm{Cd}(\mathrm{II})$, so that the obtained results can be compared with each other. Modification did not improve or maintain the process performance at the same level, but caused its reduction from $6.5 \%$ to $18.5 \%$ on average (Fig. 4a-c). In comparison, positive influence of acetic acid on the $\mathrm{Fe}$ (III) and $\mathrm{Fe}$ (II) removal was presented by Bhattacharyya et al. and Mutiara et al., respectively [16, 17].

\section{Kinetic Studies}

\section{Pseudo-First-Order and Pseudo-Second-Order Kinetic Models}

Kinetics of the bioremoval processes was studied. The parameters were calculated and are presented in Table 5. The calculated correlation coefficients $R^{2}$ did not express adequate proximity to 1.0 , thus the experimental results were further studied using another kinetic model. As a result, higher correlation coefficient values were obtained, which means that pseudo-secondorder kinetic model better describes the metal ion adsorption processes. These calculations suggest that probably chemical bonds were formed with metal ions during the adsorption on the biomass surface $[18,19]$.

\section{Adsorption Isotherms}

The biosorption processes were analysed using the Langmuir and Freundlich isotherm models. The calculated parameters are shown in Table 6. In accordance with the results, it was stated that all the processes with paprika, elderberry and gooseberry for the removal $\mathrm{Cu}(\mathrm{II}), \mathrm{Cd}(\mathrm{II})$ and $\mathrm{Fe}(\mathrm{III})$ are better suited to the Langmuir model. The difference is small in case of processes with elderberry $(\mathrm{Cu}(\mathrm{II}), \mathrm{Fe}(\mathrm{III}))$ and gooseberry $(\mathrm{Cu}(\mathrm{II}))$. In these studies, the calculated maximum adsorption capacity is in the range from 1.6 to $40.5 \mathrm{mg} / \mathrm{g}$, however the highest values were obtained for Fe(III) adsorption (Table 6).

\section{SEM Analysis}

SEM analysis of the surface of modified biosorbents after adsorption was conducted. As it is seen in

Table 4. Significant parameters of biosorption efficiency after modification with acetic acid.

\begin{tabular}{|c|c|c|c|c|c|c|}
\hline $\begin{array}{c}\text { Modified biosorbents } \\
(100 \mathrm{~g} / \mathrm{L}) \text {, metal ions }\end{array}$ & $\begin{array}{c}\text { Elderberry, } \\
\mathrm{Cu}(\mathrm{II})\end{array}$ & $\begin{array}{c}\text { Gooseberry, } \\
\mathrm{Cu}(\mathrm{II})\end{array}$ & $\begin{array}{c}\text { Paprika, } \\
\mathrm{Cu}(\mathrm{II})\end{array}$ & $\begin{array}{c}\text { Elderberry, } \\
\mathrm{Cd}(\mathrm{II})\end{array}$ & $\begin{array}{c}\text { Gooseberry, } \\
\mathrm{Cd}(\mathrm{II})\end{array}$ & $\begin{array}{c}\text { Paprika, } \\
\mathrm{Cd}(\mathrm{II})\end{array}$ \\
\hline $\begin{array}{c}\text { The greatest biosorption efficiency [\%], } \\
5 \% \text { acetic acid }\end{array}$ & 88.7 & 94.0 & 94.0 & 62.7 & 60.7 & 72.5 \\
\hline $\begin{array}{c}\text { The average increase in biosorption efficiency } \\
{[\%], 5 \% \text { acetic acid }}\end{array}$ & 24.3 & 26.3 & 25.6 & 6.7 & 4.8 & 18.7 \\
\hline $\begin{array}{c}\text { The greatest biosorption efficiency [\%], } \\
10 \% \text { acetic acid }\end{array}$ & 90.9 & 97.3 & 95.4 & 67.5 & 67.8 & 81.1 \\
\hline $\begin{array}{c}\text { The average increase in biosorption efficiency } \\
{[\%], 10 \% \text { acetic acid }}\end{array}$ & 27.0 & 33.3 & 27.5 & 11.6 & 9.6 & 28.0 \\
\hline
\end{tabular}




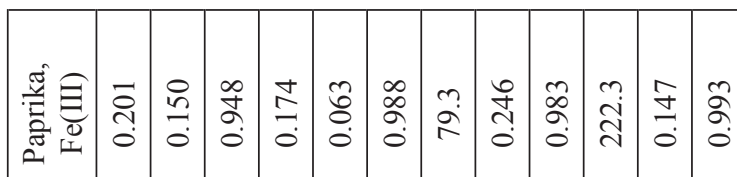

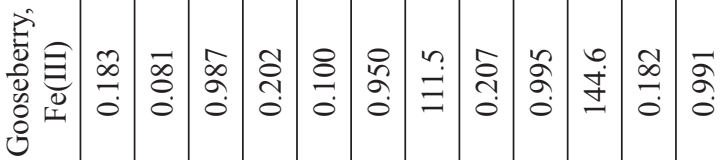

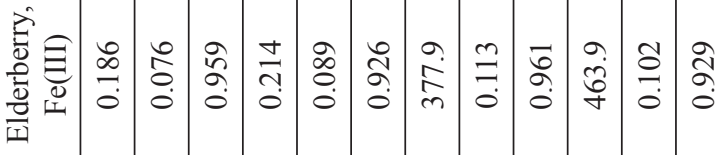

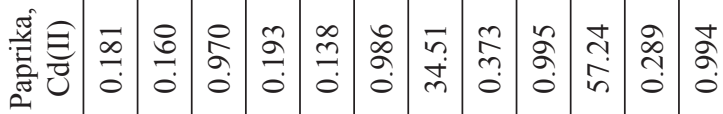

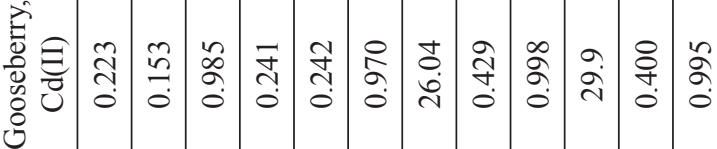

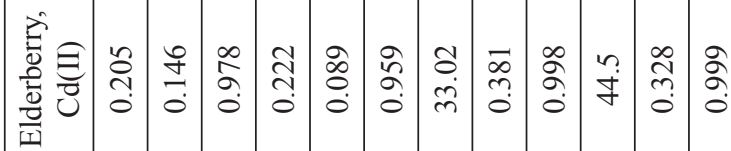

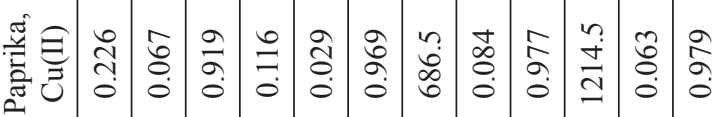

을

a

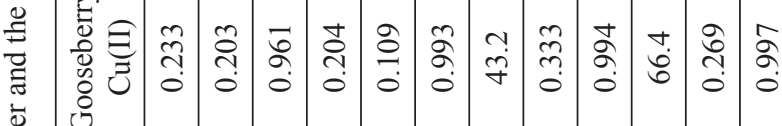

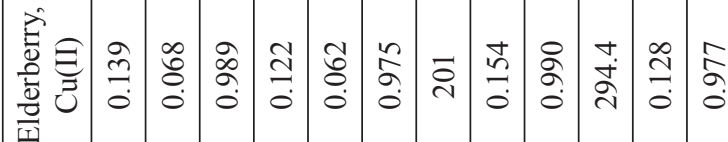

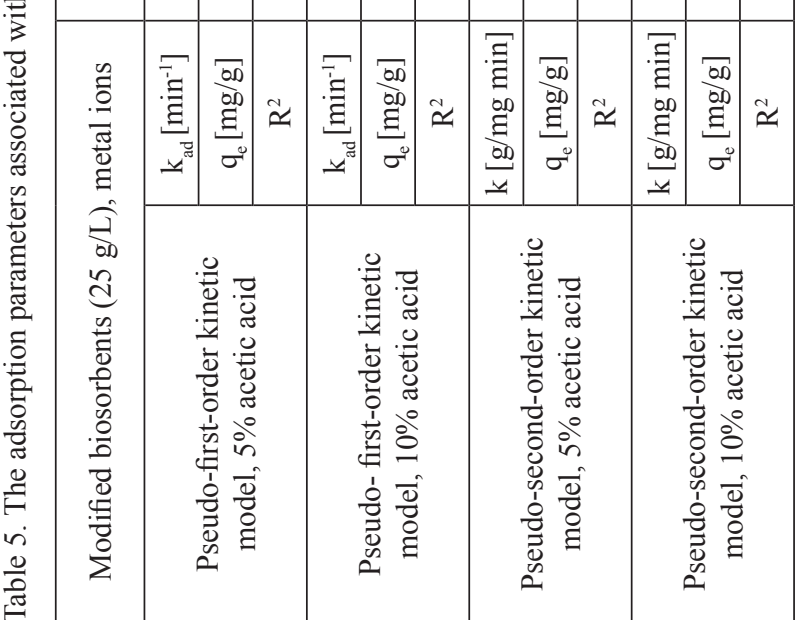

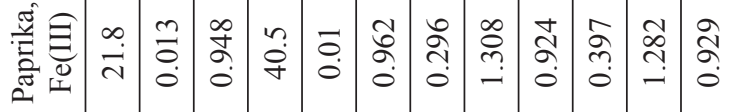

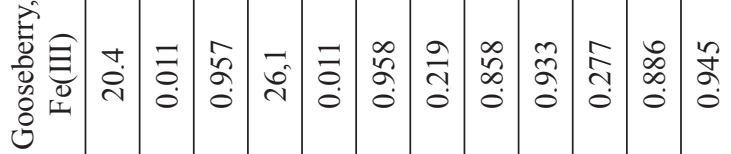

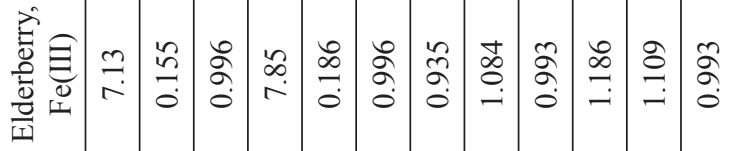

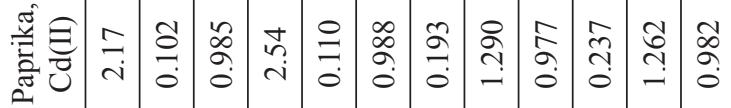

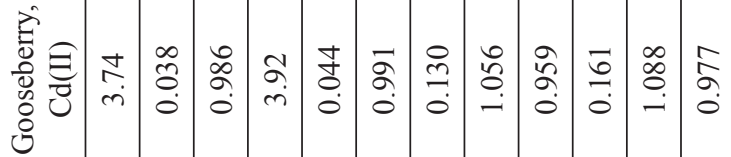

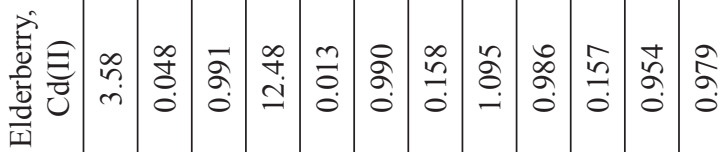

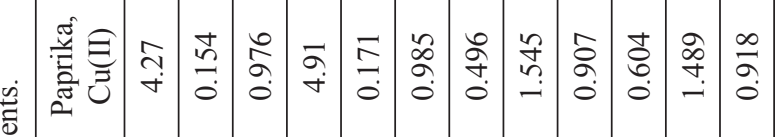

$\stackrel{\frac{0}{0}}{\mathscr{E}}$

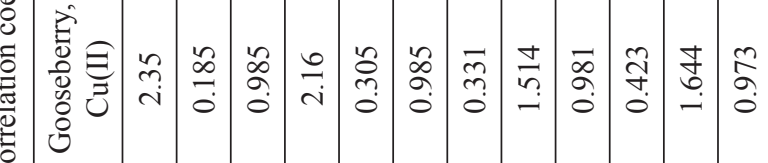

密

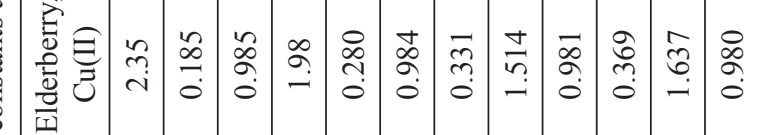

\begin{tabular}{|c|c|c|c|c|c|c|c|c|c|}
\hline 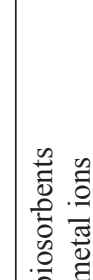 & 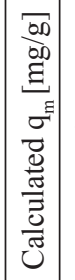 & 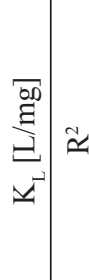 & 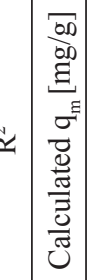 & 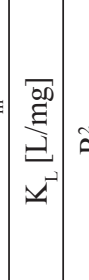 & 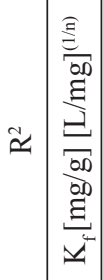 & $=$ & $\approx$ & 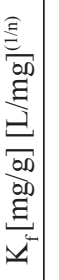 & $=\approx$ \\
\hline$e^{0}$ & 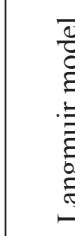 & 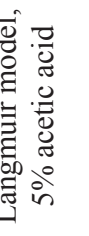 & & 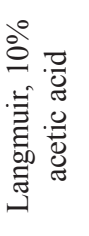 & & 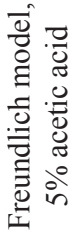 & & & 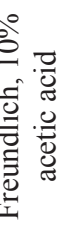 \\
\hline
\end{tabular}


a)

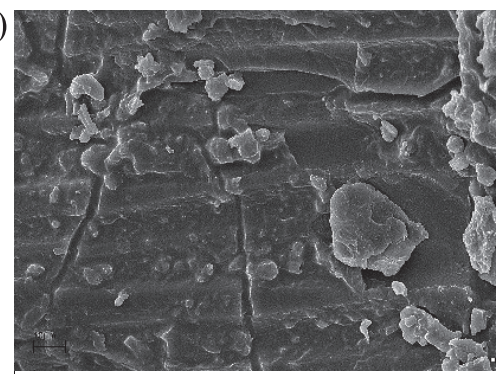

d)

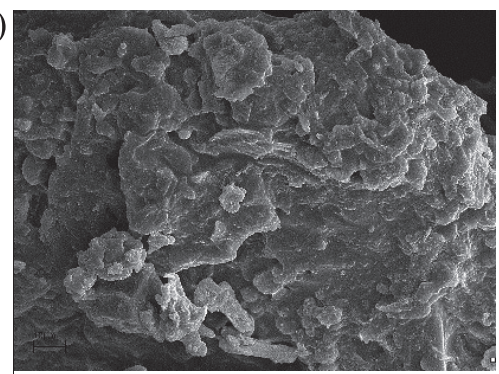

b)
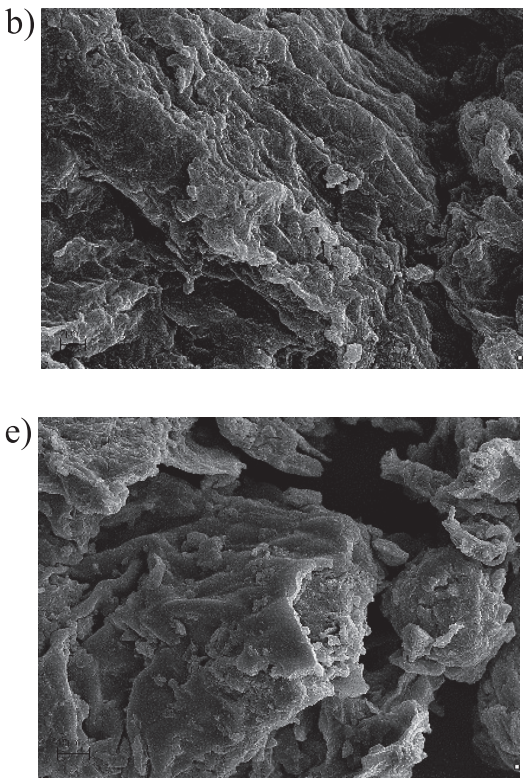
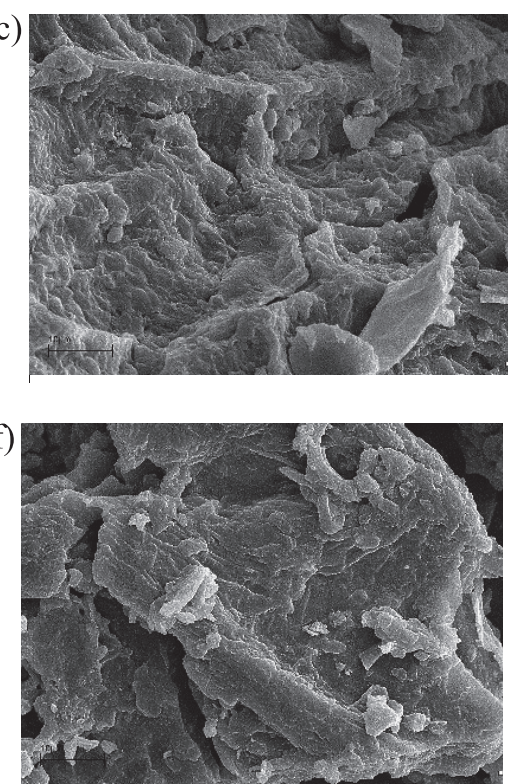

Fig. 5. The SEM images (x10000) of biosorbents after adsorption: elderberry $(\mathrm{a}-\mathrm{Cu}(\mathrm{II}), \mathrm{d}-\mathrm{Cd}(\mathrm{II}))$, gooseberry $(\mathrm{b}-\mathrm{Cu}(\mathrm{II}), \mathrm{e}-\mathrm{Cd}(\mathrm{II}))$, paprika (c- $\mathrm{Cu}(\mathrm{II}), \mathrm{f}-\mathrm{Cd}(\mathrm{II}))$.

Fig. 5(a-f), numerous surface cavities and convexities are typical for the biomass. These irregular shapes are presented in oval, longitudinal and mild forms as well as with sharp endings in many places. Greater irregularity occurs with larger particles than smaller ones. Generally stating, the structure is not homogeneous and developed flat surfaces are present with a large amount of small agglomerates attached to larger parts of the materials. After activation with acetic acid and the process of adsorption of metal ions, the surface looks more irregular, rough, many small gaps have been filled and agglomeration of particles has occurred. These characteristic texture features can probably be confirmation of the reaction of metal ions with active centers of modified biomass surfaces.

\section{FT-IR Analysis}

The FT-IR analysis of the modified biosorbents before and after sorption processes was realized and the spectra are shown in Fig. 6(a-c). The peak designations are given in Table 7. The spectra were analysed and compared with each other, taking into account differences in the shape, intensity and frequency of the bands or possible interactions with metal ions. The course of FT-IR spectra indicates that after adsorption

Table 7. FT-IR peaks of modified biosorbents and their assignment.

\begin{tabular}{|c|c|}
\hline FT-IR band $\left[\mathrm{cm}^{-1}\right]$ & Assignment (vibrations, species) \\
\hline $\begin{array}{c}3283,3284,3285,3286,3287,3300,3301, \\
3302,3318\end{array}$ & Stretching O-H from water and other hydroxylated molecules (alcohols, phenols) \\
\hline $2922,2923,2924,2925,2926$ & Asymmetric stretching $\mathrm{C}-\mathrm{H}_{,}-\mathrm{CH}_{3}$ and $-\mathrm{CH}_{2}$ - groups (carboxylic acids) \\
\hline $2852,2853,2855$ & Stretching $\mathrm{C}-\mathrm{H},-\mathrm{CH}_{3}$ groups \\
\hline $1730,1731,1733,1734,1736,1737$ & Stretching C=O (esters) \\
\hline $1623,1626,1627,1628,1631,1643$ & Stretching C-O \\
\hline $1513,1515,1516,1517,1518$ & Bending N-H; stretching C=C (aromatic ring) \\
\hline $1439,1440,1441,1446,1453$ & Bending O-H, bending C-H (-CH group from proteins) \\
\hline 1380 & Deformation vibration C-H \\
\hline 1300 & Deformation vibration C-O, O-H (poliphenols) \\
\hline 1234,1235 & Stretching C-O-C \\
\hline 1150 & Deformation vibration C-H, C-O, bending C-C (carbohydrates) \\
\hline $1026,1027,1028,1029$ & Bending C-O (polysaccharides) \\
\hline
\end{tabular}




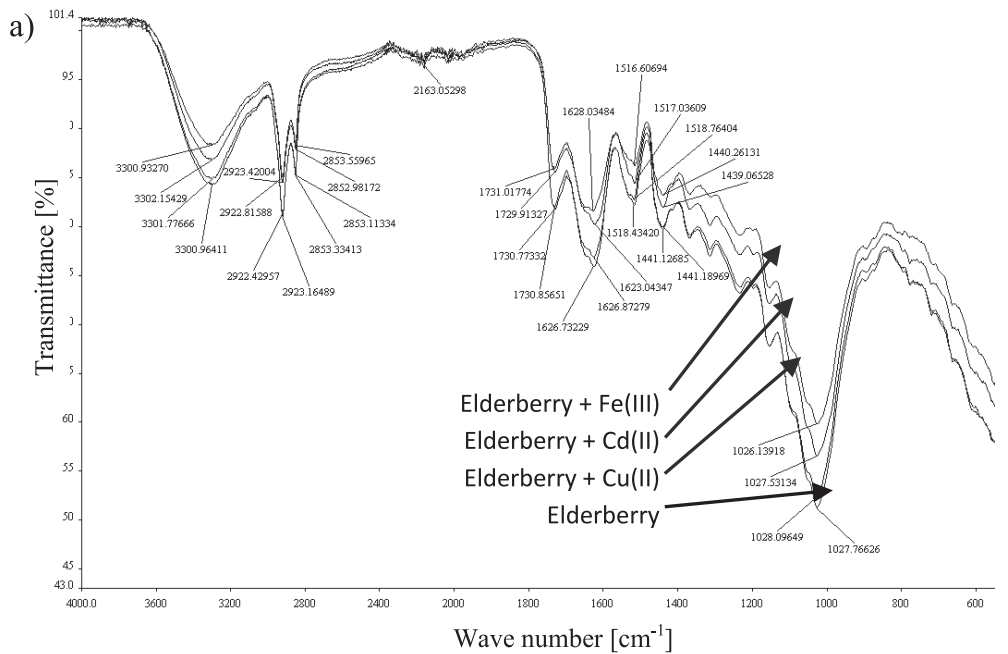

b)

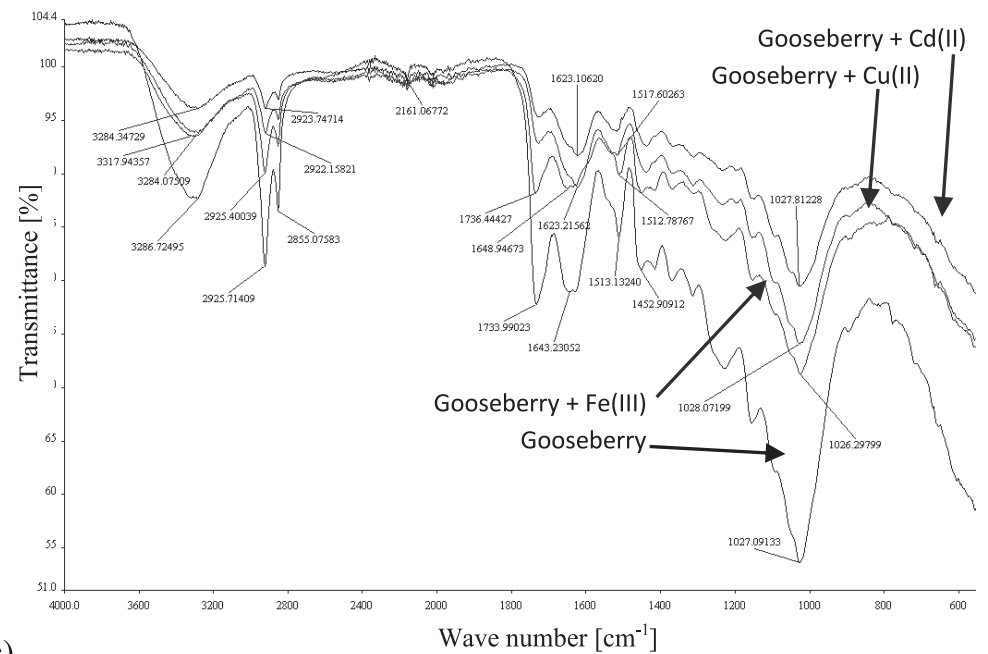

c)

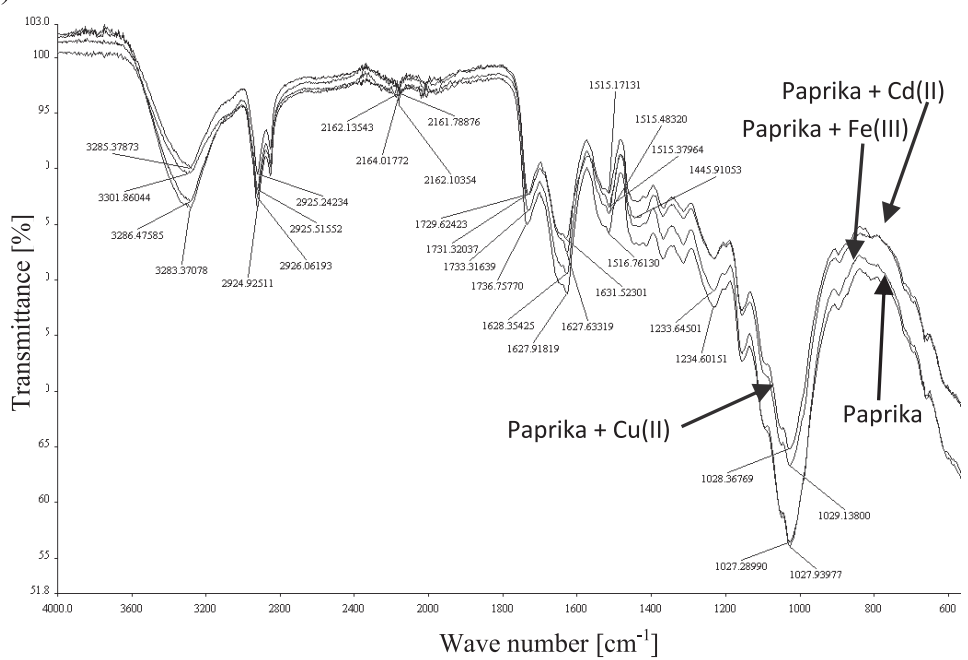

Fig. 6. FT-IR spectra before and after $\mathrm{Cu}(\mathrm{II}), \mathrm{Cd}(\mathrm{II}), \mathrm{Fe}(\mathrm{III})$ ions biosorption by modified biomass: a) elderberry, b) gooseberry, c) paprika.

processes the intensity of peaks shifted towards higher transmittance values and their positions remained at the same wavelengths or were slightly shifted in some cases. Slight shifts were noted at the following peaks: 3286, 3287, 3301, 2923, 2925, 2926, 2854, 2855, 1731,
1734, 1737, 1627, 1628, 1643, 1513, 1517, 1519 and 1027, $1028 \mathrm{~cm}^{-1}$. These changes may be a consequence of the interaction of $\mathrm{Cu}(\mathrm{II}), \mathrm{Cd}(\mathrm{II})$ and $\mathrm{Fe}(\mathrm{III})$ metal ions with functional groups of organic compounds present in biomass through the chemisorption process. 


\section{Conclusions}

In this work, elderberry (Sambucus nigra L.), gooseberry (Ribes uva-crispa L.) and paprika (Capsicum annuит L.) residues obtained during processing in the food industry were chemically modified with acetic acid and next examined for the removal $\mathrm{Cu}(\mathrm{II}), \mathrm{Cd}(\mathrm{II})$ and $\mathrm{Fe}(\mathrm{III})$ ions from aqueous solutions. In initial research, physicochemical properties of the biomaterials were determined by the use of various analytical methods. Further studies revealed that as a result of surface modification with 5\% acetic acid, the average increase in adsorption efficiency for elderberry, gooseberry and paprika was as follows: $24.3 \%, 26.3 \%, 25.6 \%$ for $\mathrm{Cu}(\mathrm{II})$ and $6.7 \%, 4.8 \%, 18.7 \%$ for $\mathrm{Cd}(\mathrm{II})$, respectively. In case of modification with $10 \%$ acetic acid, the increase was a bit higher: $27.0 \%, 33.3 \%, 27.5 \%$ for $\mathrm{Cu}(\mathrm{II})$ and $11.6 \%$, $9.6 \%, 28.0 \%$ for $\mathrm{Cd}(\mathrm{II})$, respectively. The greatest efficiency (97.3\%) was reported in the biosorption process of $\mathrm{Cu}(\mathrm{II})$ ions by modified gooseberry pomace. No improvement in adsorption results was observed in the $\mathrm{Fe}(\mathrm{III})$ ion removal process. Based on the analysis of process kinetics and isotherms, characteristic parameters and correlation coefficients were calculated. It was found that all adsorption reactions after modification are better described by the pseudo-secondorder kinetic model and the Langmuir isotherm model.

In summary, the study showed that the chemical modification of biomass with acetic acid had a positive effect on improving the efficiency of the biosorption process in relation to copper and cadmium ions. The achieved research success can certainly be a clue to the industrial use of this technological solution to improve the quality of fresh water.

\section{Acknowledgements}

This research did not receive a specific grant from any funding agency in the public, commercial or notfor-profit sectors.

\section{Conflict of Interest}

The authors have declared no conflict of interest.

\section{References}

1. RAMIREZ O.H., HOLMES S.M. Novel and modified materials for wastewater treatment applications. Journal of Materials Chemistry, 18, 2751, 2008.

2. HEGAZI H.A. Removal of heavy metals from wastewater using agricultural and industrial wastes as adsorbents. Housing and Building National Research Center, 9 (3), 276, 2013.

3. DWIVEDI A.K. Researches in water pollution: a review. International Research Journal of Natural and Applied Sciences, 4, 118, 2017.
4. AKPOR O.B., OHIOBOR G.O., OLAOLU T.D. Heavy Metal Pollutants in Wastewater Effluents: Sources, Effects and Remediation. Advances in Bioscience and Bioengineering, 2, 37, 2014.

5. KALAK T., KŁOPOTEK A., CIERPISZEWSKI R. Effective adsorption of lead ions using fly ash obtained in the novel circulating fluidized bed combustion technology. Microchemical Journal, 145, 1011, 2019.

6. BISHT R., AGARWAL M., SINGH K. Methodologies for removal of heavy metal ions from wastewater: an overview. Interdisciplinary Environmental Review, 18, 124, 2017.

7. KALAK T., DUDCZAK J., CIERPISZEWSKI R. Adsorption behaviour of copper ions on elderberry, gooseberry and paprika waste from aqueous solutions. Proceedings of 12th International Interdisciplinary Meeting on Bioanalysis (CECE), Brno, Czech Republic, 123-127, 2015.

8. INOUE K., PARAJULI D., GHIMIRE K.N., BISWAS B.K., KAWAKITA H., OSHIMA T., OHTO K., Biosorbents for Removing Hazardous Metals and Metalloids. Materials, 10, 857, 2017.

9. SAMORAI M., TUHY Ł., CHOJNACKA K. Valorization of Biomass into Micronutrient Fertilizers. Waste and Biomass Valorization, 10, 925, 2017.

10. AMBROZ F., MACDONALD T.J., MARTIS V., PARKIN I.P. Evaluation of the BET Theory for the Characterization of Meso and Microporous MOFs. Small methods, 2, 1, 2018.

11. NARAYAN R., NAYAK U.Y., RAICHUR A.M., GARG S. Mesoporous Silica Nanoparticles: A Comprehensive Review on Synthesis and Recent Advances. Pharmaceutics, 10, 118, 2018.

12. KALAK T., DUDCZAK J., SZYCHOWIAK E., CIERPISZEWSKI R. Biosorption of $\mathrm{Cu}$ (II) and $\mathrm{Cd}(\mathrm{II})$ Heavy Metals from Aqueous Solutions by Paprika Waste. Studia Oeconomica Posnaniensia, 5, 104, 2017.

13. KALAK T., CIERPISZEWSKI R. Comparative studies on the adsorption of $\mathrm{Pb}(\mathrm{II})$ ions by fly ash and slag obtained from CFBC technology. Polish Journal of Chemical Technology, 21, 72, 2019.

14. KALAK T., DUDCZAK-HAŁABUDA J., TACHIBANA Y., CIERPISZEWSKI R. Effective use of elderberry (Sambucus nigra) pomace in biosorption processes of $\mathrm{Fe}(\mathrm{III})$ ions. Chemosphere, 246, 2020.

15. SHA L., XUEYI G., NINGCHUAN F., QINGHUA T. Adsorption of $\mathrm{Cu}^{2+}$ and $\mathrm{Cd}^{2+}$ from aqueous solution by mercapto-acetic acidmodified orange peel. Colloids and Surfaces B: Biointerfaces, 73, 10, 2009.

16. BHATTACHARYYA K.G., GUPTA S.S. Adsorption of $\mathrm{Fe}$ (III) from water by natural and acid activated clays: Studies on equilibrium isotherm, kinetics and thermodynamics of interactions. Adsorption, 12, 185, 2006.

17. MUTIARA T., KARISA P.C., MUJAHIDAH I. Acid modified jackfruit wood sawdust as biosorbent for the removal of $\mathrm{Fe}(\mathrm{II})$ from aqueous solutions. MATEC Web of Conferences, 154, 1, 2018.

18. MAHMOUD M.A. Kinetics and thermodynamics of aluminum oxide nanopowder as adsorbent for Fe(III) from aqueous solution. Beni-Suef University Journal of Basic and Applied Sciences, 4, 142, 2015.

19. ARSHADI M., AMIRI M.J., MOUSAVI S. Kinetic, equilibrium and thermodynamic investigations of $\mathrm{Ni}(\mathrm{II})$, $\mathrm{Cd}(\mathrm{II}), \mathrm{Cu}(\mathrm{II})$ and $\mathrm{Co}(\mathrm{II})$ adsorption on barley straw ash. Water Resources and Industry, 6, 1, 2014. 


\section{Supplementary Material}

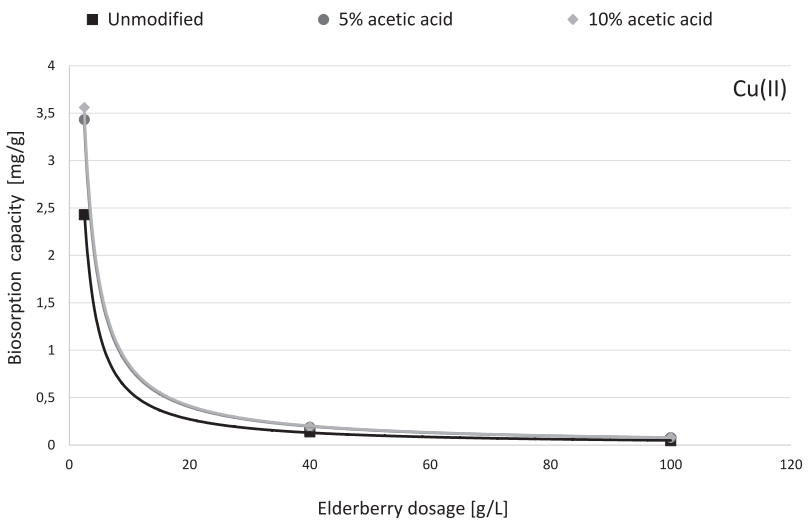

Fig. 1. Effect of adsorbent dosage on biosorption capacity of $\mathrm{Cu}$ (II) by $\mathrm{CH}_{3} \mathrm{COOH}$-modified elderberry residues (initial concentration of $\mathrm{Cu}$ (II) $10.87 \mathrm{mg} / \mathrm{L}$; initial $\mathrm{pH} 4$ ).

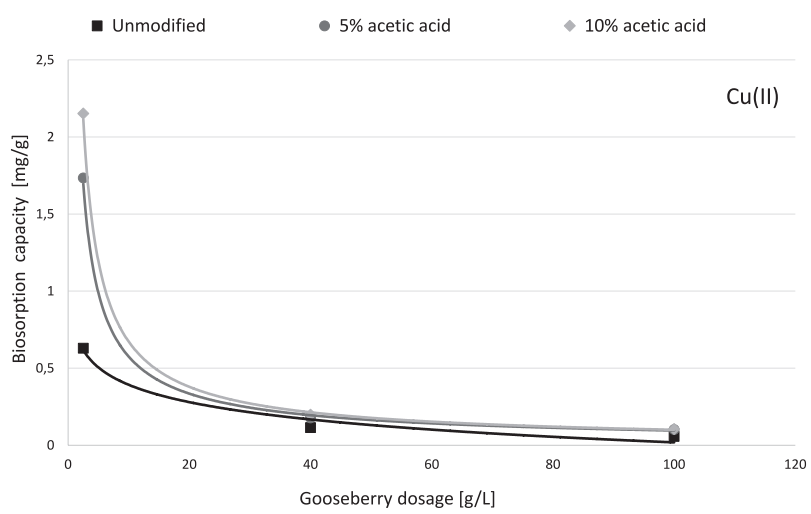

Fig. 2. Effect of adsorbent dosage on biosorption capacity of $\mathrm{Cu}$ (II) by $\mathrm{CH}_{3} \mathrm{COOH}$-modified gooseberry residues (initial concentration of $\mathrm{Cu}(\mathrm{II}) 10.87 \mathrm{mg} / \mathrm{L}$; initial $\mathrm{pH} 4$ ).

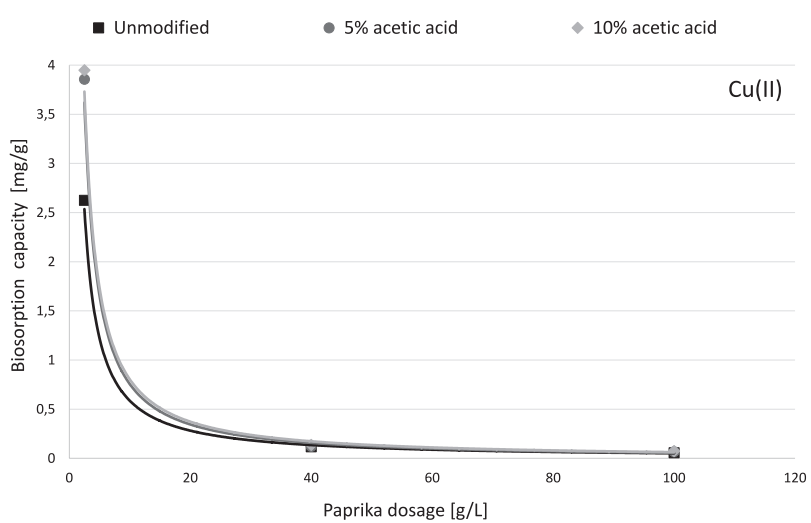

Fig. 3. Effect of adsorbent dosage on biosorption capacity of $\mathrm{Cu}(\mathrm{II})$ by $\mathrm{CH}_{3} \mathrm{COOH}$-modified paprika residues (initial concentration of $\mathrm{Cu}(\mathrm{II}) 10.87 \mathrm{mg} / \mathrm{L}$; initial $\mathrm{pH} 4$ ).

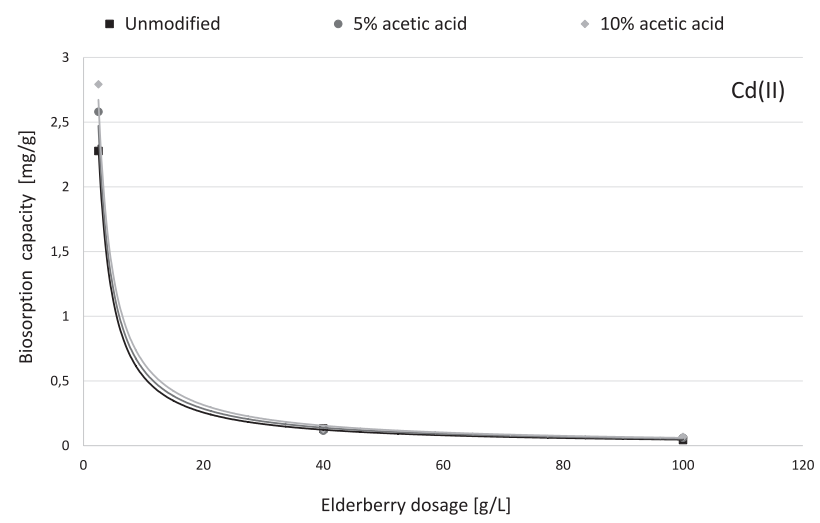

Fig. 4. Effect of adsorbent dosage on biosorption capacity of $\mathrm{Cd}$ (II) by $\mathrm{CH}_{3} \mathrm{COOH}$-modified elderberry residues (initial concentration of $\mathrm{Cd}(\mathrm{II}) 11.56 \mathrm{mg} / \mathrm{L}$; initial $\mathrm{pH} 4$ ).

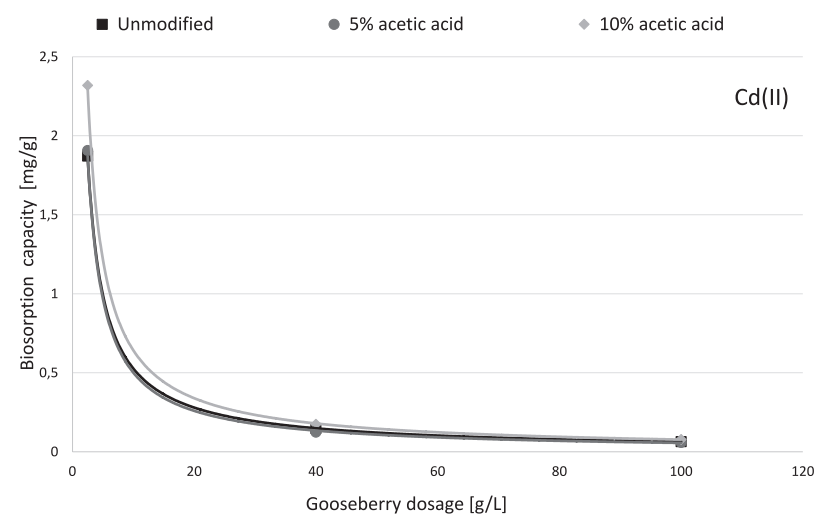

Fig. 5. Effect of adsorbent dosage on biosorption capacity of $\mathrm{Cd}$ (II) by $\mathrm{CH}_{3} \mathrm{COOH}$-modified gooseberry residues (initial concentration of $\mathrm{Cd}(\mathrm{II}) 11.56 \mathrm{mg} / \mathrm{L}$; initial $\mathrm{pH} 4$ ).

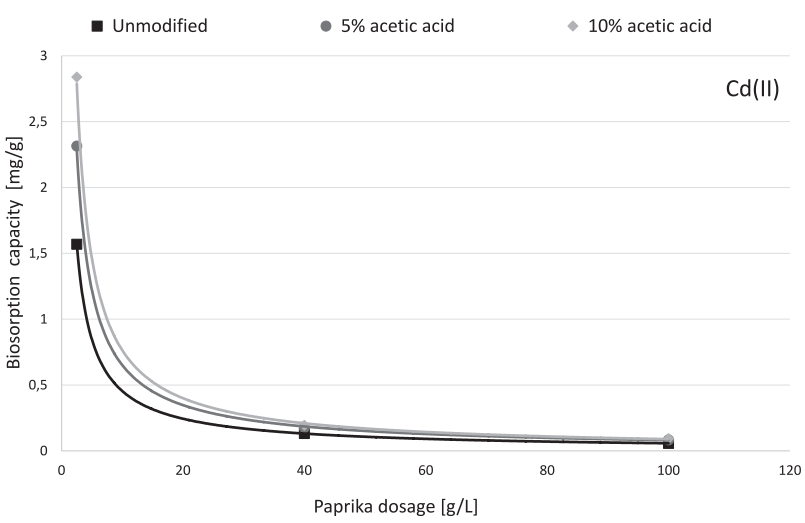

Fig. 6. Effect of adsorbent dosage on biosorption capacity of $\mathrm{Cd}(\mathrm{II})$ by $\mathrm{CH}_{3} \mathrm{COOH}$-modified paprika residues (initial concentration of Cd(II) $11.56 \mathrm{mg} / \mathrm{L}$; initial $\mathrm{pH} 4$ ). 
- Unmodified

- $5 \%$ acetic acid

- $10 \%$ acetic acid

$$
3
$$

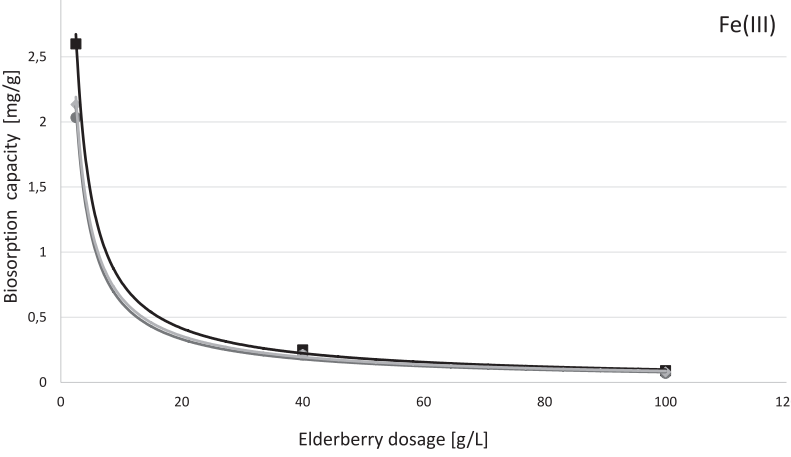

Fig. 7. Effect of adsorbent dosage on biosorption capacity of $\mathrm{Fe}$ (III) by $\mathrm{CH}_{3} \mathrm{COOH}$-modified elderberry residues (initial concentration of $\mathrm{Fe}(\mathrm{III}) 9.24 \mathrm{mg} / \mathrm{L}$; initial $\mathrm{pH} 4$ ).

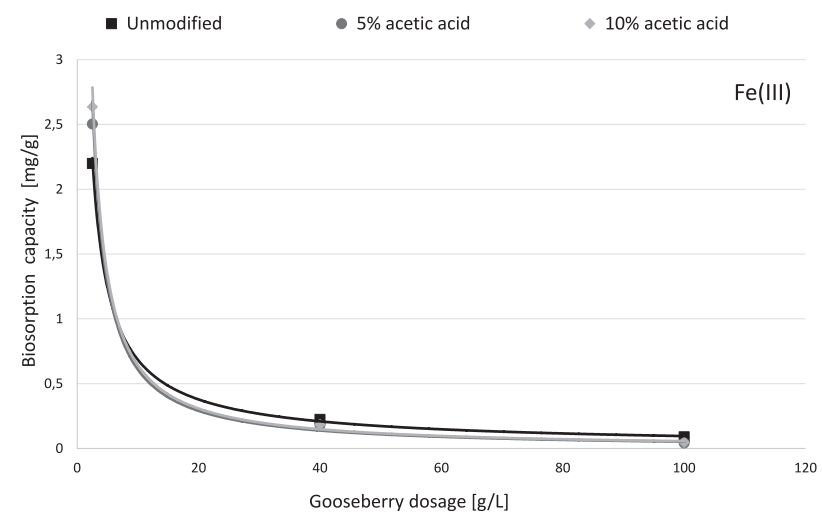

Fig. 8. Effect of adsorbent dosage on biosorption capacity of $\mathrm{Fe}(\mathrm{III})$ by $\mathrm{CH}_{3} \mathrm{COOH}$-modified gooseberry residues (initial concentration of $\mathrm{Fe}(\mathrm{III}) 9.24 \mathrm{mg} / \mathrm{L}$; initial $\mathrm{pH} 4$ ).

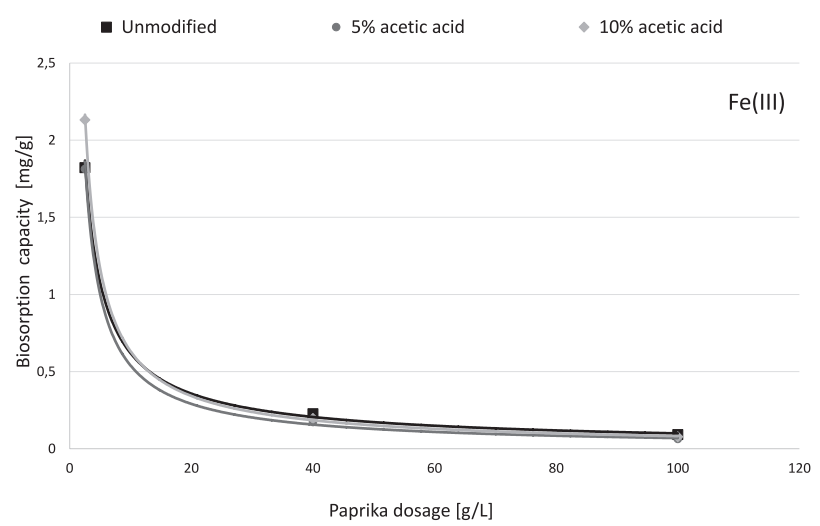

Fig. 9. Effect of adsorbent dosage on biosorption capacity of $\mathrm{Fe}(\mathrm{III})$ by $\mathrm{CH}_{3} \mathrm{COOH}$-modified paprika residues (initial concentration of $\mathrm{Fe}(\mathrm{III}) 9.24 \mathrm{mg} / \mathrm{L}$; initial $\mathrm{pH} 4$ ). 